\title{
Effect of Salicylic Acid on the Growth, Photosynthetic Efficiency and Enzyme Activities of Leguminous Plant under Cadmium Stress
}

\author{
Mohammed N. ALYEMENI ${ }^{1}$, Qaiser HAYAT ${ }^{2}$, Leonard WIJAYA ${ }^{1}$, Shamsul HAYAT ${ }^{1,2 *}$
}

\author{
${ }^{1}$ King Saud University, College of Science, Department of Botany and Microbiology, Riyadh 11451, Saudi Arabia; \\ hayat_68@yahoo.co.in ("correspondingauthor) \\ ${ }^{2}$ Aligarh Muslim University, Department of Botany, Plant Physiology Section, Aligarh 202002, Uttar Pradesh, India
}

\begin{abstract}
The present study was designed with an objective to elucidate the effect of the exogenous application of $10^{-5} \mathrm{M}$ of salicylic acid (SA) to the foliage of the chickpea plants exposed to $0,25,50$ or $100 \mathrm{mg}$ cadmium (Cd) per $\mathrm{kg}$ of soil. The foliage of the plants grown in soil amended with varying doses of $\mathrm{Cd}$ was sprayed with $10^{-5} \mathrm{M}$ of $\mathrm{SA}$ at 30 days after sowing (DAS). The plant samples were collected at 60 and 90 DAS to assess various parameters. The damage caused due to the $\mathrm{Cd}$ exposure was partially overcome by the exogenous application of SA. The SA treatment resulted in a significant increase of growth, photosynthesis, yield and the activity of antioxidative enzymes viz. catalase, peroxidase and superoxide dismutase in the plants exposed to 0,25 or $50 \mathrm{mg} \mathrm{Cd}$ per $\mathrm{kg}$ of soil. However, the treatment did not prove to be fruitful in alleviating completely the stress generated by $100 \mathrm{mg} \mathrm{Cd} \mathrm{per} \mathrm{kg}$ of soil.
\end{abstract}

Keywords: catalase, chickpea, peroxidase, photosynthesis, superoxide dismutase, yield

\section{Introduction}

Metal contamination issues are becoming increasingly throughout the world (Foy et al., 1978), with many documented cases of metal toxicity including in mining and agriculture practices. Metals are a natural part of terrestrial systems occurring in soil, rock, air, water and organisms. A few metals, including $\mathrm{Cu}, \mathrm{Mn}$ and $\mathrm{Zn}$, are however essential to plant metabolism in trace amounts. It has potential to become toxic to plants when metals are present in bioavailable forms at excessive levels. On the other hand, Cd is a non-essential trace element for plants, and has strong toxicity at low concentrations with the ability to readily absorb by roots (Sanita di Toppi and Gabbrielli, 1999). It can suppress the elongation growth of plant cell, inhibit oxidative mitochondrial phosphorylation, induce oxidative stress, inhibit the activities of several antioxidative enzymes, affect photosynthesis by inhibiting ferrous reductase or damaging photosynthesis apparatus, and cause the alteration of chromatin and the change of plasma membrane ATPase activity (Tran and Popova, 2013). Cadmium also causes various direct and indirect effects on plant growth and metabolism (Hasan et al., 2009) by forming complexes with $\mathrm{O}, \mathrm{N}$ and $\mathrm{S}$ ligands (Van Assche and Clijsters, 1990). It interferes with protein metabolism,membrane functioning and water relations (Irfan et al., 2013). Cadmium inhibited net photosynthesis in Cajanus cajan (Sheoran et al., 1990) and Phaseolus vulgaris (Krupa et al., 1993), $\mathrm{O}_{2}$ evolution in Anacystis nedulens and photosystem II (PS II) in isolated chloroplasts of maize and spinach (Bazzas et al., 1974). Moreover, they cause metabolic disturbance by altering essential biochemical reactions (Hermans et al., 2004). Exposure to $\mathrm{Cd}$ stress disrupt cellular homeostasis and enhances the production of several activated oxygen species designated as reactive oxygen species (ROS) such as superoxide $\left(\mathrm{O} 2^{--}\right)$, hydroxyl radicals $(\mathrm{OH})$, singlet oxygen $\left({ }^{1} \mathrm{O}_{2}\right)$, and hydrogen peroxide $\left(\mathrm{H}_{2} \mathrm{O}_{2}\right)$ that are produced continuously by plants (Foyer and Noctor, 2003). ROS have been shown to damage cell membranes, proteins, lipids, and DNA (causing inter alia DNA base oxidation, DNA protein cross-links, DNA gaps, and breaks) resulting in lipid peroxidation (Skórzyńska-Polit and Krupa, 2006), developmental defects, and genetic instability in plant species (Bal et al., 2000). However, plants possess very efficient enzymatic and non-enzymatic antioxidant defense systems that allow scavenging of ROS and protection of cell to oxidative damage (Gratão et al., 2005).

Salicylic acid (SA) is a phenolic compound synthesized throughout the plant kingdom via the phenylpropanoid pathway (Métraux, 2002). Over the past decade, various workers documented that this molecule plays vital roles in many physiological processes of plants and also have ability to confer tolerance against various abiotic stresses (Janda et al., 2007; Hayat et al., 2013). SA application at a concentration of 0.1 or $0.2 \mathrm{mM}$ reduced the inhibitory effect of $\mathrm{Pb}^{2+}$ and $\mathrm{Hg}^{2+}$ on the seed germination and seedling growth of two rice (Oryza sativa L.) cultivars (Mishra and Choudhuri, 1997). SA increased the fresh and dry mass of shoots and roots in both cultivars under heavy metal stress conditions. The higher concentration of SA was more effective, as evident from a better recovery from metal- 
441

induced growth inhibition. SA moderated the inhibitory effect of lead on the activity of the nitrate reductase enzyme in maize (Zea mays L.) plants (Sinha et al., 1994). This suggests that SA has some role in the tolerance of plants to heavy metal stress, though other authors found no increase in the endogenous SA content as the result of Cd treatment, or any difference in the SA content of sensitive and resistant plants of Salix viminalis in the control (Landberg and Greger, 2002).

On the basis of above reports, the primary objective of this work was to examine whether or not SA could mitigate the Cd-induced oxidative stress in legumes by regulating the antioxidant defense system and also dissect the efficiency of photosynthetic machinery under $\mathrm{Cd}$ stress in the presence as well as absence of SA.

\section{Materials and methods}

The certified seeds of Cicer arietinum L. cv. 'Avarodhi' were purchased from the Chola Beejh Bhandar, Aligarh, India. The seeds were surface sterilized with $0.01 \%$ mercuric chloride solution followed by inoculation with Rhizobium and were sown in five sets of earthen pots (10 inch diameter) filled with sandy loam soil and farmyard manure (6:1) arranged under a simple randomized block design. At the start of the experiment, out of these five sets of prepared pots, four sets were supplemented with different doses $(0,25,50$ or $100 \mathrm{mg}$ per $\mathrm{kg}$ of soil) of $\mathrm{Cd}$ in the form of $\mathrm{CdCl}_{2}$ respectively and one set of pots was left untreated serving as control. At the stage of $30 \mathrm{DAS}$, the foliage of the resulting plants was sprayed with $10^{-5} \mathrm{M}$ of salicylic acid (SA), except control which received double distilled water (DDW) instead of SA. The concentration of SA was selected on the basis of our earlier experiments (Hayat et al., 2010). The plant samples were collected at 60 and 90 DAS to assess various growth and physiological parameters.

\section{Plant growth analysis}

The plants were uprooted and washed under running tap water. The root and shoot length of these plants was measured with the help of a graduated scale. These plants were blotted in blotting sheets to remove the adhering water and weighed on electronic balance to record their fresh mass. These plants were kept in an oven run at $80^{\circ} \mathrm{C}$ for 72 hours and then weighed to obtain their dry mass.

\section{Carbonic anhydrase (CA) activity}

The CA activity in the leaves was measured by following the method described by Dwivedi and Randhawa (1974).

\section{Photosynthetic measurements}

The stomatal conductance $\left(\mathrm{g}_{\mathrm{s}}\right)$, intercellular $\mathrm{CO}_{2}$ concentration $\left(\mathrm{C}_{\mathrm{i}}\right)$, transpiration rate $(\mathrm{E})$, water use efficiency (WUE) and net photosynthetic rate $\left(\mathrm{P}_{\mathrm{N}}\right)$ in intact leaves were measured using a portable photosynthetic system, between 11:00 and 12:00 $\mathrm{h}$.

\section{Assay of antioxidative enzymes}

The activities of peroxidase (POX) and catalase (CAT) were analysed as per the method described by Chance and Maehly (1956) whereas the superoxide dismutase (SOD) was measured by the method of Beauchamp and Fridovich
(1971).

\section{Proline content in leaves}

The proline content in the fresh leaf sample was measured following the method described by Bates et al. (1973).

\section{Yield Characteristics}

At harvest (160 DAS), three plants from each treatment were randomly sampled and counted for the number of pods per plant. The pods from five plants, representing each treatment, were crushed, cleaned to assess the seed weight per plant and 100 seed mass.

\section{Seed protein content}

The total protein content in the dry seeds, at harvest, was estimated by adopting the method of Lowry $e t$ al. (1951).

\section{Statistical analysis}

Each observation was replicated three times. The treatment means were compared by analysis of variance using SPSS software version 10 (SPSS, Chicago, IL, USA). Least significant difference (LSD) was calculated at $5 \%$ level of probability. Standard error (SE) due to replicates was also calculated.

\section{Results}

\section{Length of root and shoot}

Foliar application of $10^{-5} \mathrm{M}$ of SA significantly increased the length of root and shoot by $33.3 \%, 40.0 \%$ and $29.4 \%$, $30.2 \%$ in unstressed plants, $22.5 \%, 26.1 \%$ and $16.7 \%, 18.0 \%$ in the plants exposed to Cd at the rate of $25 \mathrm{mg}$ per $\mathrm{kg}$ of soil and $13.0 \%, 14.5 \%$ and $7.5 \%, 8.2 \%$ in the plants exposed to a Cd stress of $50 \mathrm{mg}$ per $\mathrm{kg}$ of soil, at 60 and 90 DAS, respectively, over their controls (Tab. 1). However, the spray proved to be inefficient in alleviating the stress generated by $\mathrm{Cd}$, supplemented at the rate of $100 \mathrm{mg}$ per $\mathrm{kg}$ of soil.

\section{Fresh and dry mass per plant}

Exogenous application of $10^{-5} \mathrm{M}$ of SA resulted in a significant increase of $44.4 \%, 46.9 \%$ and $64.5 \%, 64.9 \%$ in the fresh and dry mass of unstressed plants and $17.8 \%$, $21.2 \%$ and $19.3 \%, 13.5 \%$ in those exposed to $\mathrm{Cd}$ supplemented at the rate of $25 \mathrm{mg}$ per $\mathrm{kg}$ of soil, at 60 and

Tab. 1. Effect of $10^{-5} \mathrm{M}$ salicylic acid (SA) on the Cd (0, 25, 50 or 100 $\mathrm{mg} \mathrm{kg}{ }^{-1}$ of soil) induced changes in root and shoot length plant ${ }^{-1}$ in Cicer arietinum at 60 and 90 DAS. Data are the mean of three independent replicates $( \pm \mathrm{SE})$

\begin{tabular}{ccccc}
\hline \multirow{2}{*}{ Treatments } & \multicolumn{2}{c}{ Root length $(\mathrm{cm})$} & \multicolumn{2}{c}{ Shoot length $(\mathrm{cm})$} \\
\cline { 2 - 5 } & 60 DAS & 90 DAS & 60 DAS & 90 DAS \\
\hline Control (DDW) & $14.34^{\mathrm{b}} \pm 1.6$ & $17.12^{\mathrm{c}} \pm 3.8$ & $36.54^{\mathrm{c}} \pm 0.11$ & $41.25^{\mathrm{c}} \pm 0.15$ \\
$\mathrm{Cd}(0 \mathrm{mg})+\mathrm{SA}$ & $18.53^{\mathrm{a}} \pm 1.7$ & $22.50^{\mathrm{a}} \pm 3.5$ & $47.25^{\mathrm{a}} \pm 0.15$ & $52.35^{\mathrm{a}} \pm 0.17$ \\
$\mathrm{Cd}(25 \mathrm{mg})+$ SA & $17.32^{\mathrm{a}} \pm 3.5$ & $20.15^{\mathrm{b}} \pm 3.2$ & $41.25^{\mathrm{b}} \pm 0.18$ & $46.92^{\mathrm{b}} \pm 0.20$ \\
$\mathrm{Cd}(50 \mathrm{mg})+$ SA & $15.84^{\mathrm{b}} \pm 4.0$ & $17.38^{\mathrm{c}} \pm 2.9$ & $39.11^{\mathrm{b}} \pm 0.1$ & $41.78^{\mathrm{c}} \pm 0.12$ \\
Cd $(100 \mathrm{mg})+$ SA & $12.78^{\mathrm{c}} \pm 2.9$ & $14.65^{\mathrm{d}} \pm 4.0$ & $32.15^{\mathrm{d}} \pm 0.2$ & $35.56^{\mathrm{d}} \pm 0.11$ \\
LSD $\%$ & 1.32 & 1.56 & 2.95 & 3.25 \\
\hline
\end{tabular}


90 DAS, respectively, compared to the control (Tab. 2). Further, the fresh mass per plant was recorded to be statistically equal at day 60 to that of control in the plants fed with $\mathrm{Cd}$ at the rate of $50 \mathrm{mg}$ per $\mathrm{kg}$ of soil, followed by foliar spray of $10^{-5} \mathrm{M}$ of SA, whereas, at 90 DAS, the fresh mass per plant was recorded to be $10.0 \%$ higher compared to that of control. The hormonal spray resulted in a significant increase of $12.9 \%$ and $5.4 \%$ at 60 and 90 DAS, respectively, compared to the control, in the dry mass of the plants supplemented with $50 \mathrm{mg} \mathrm{Cd}$ per $\mathrm{kg}$ of soil. However, like that of root length and shoot length foliar spray of SA proved to be inefficient in alleviating the stress (Cd $100 \mathrm{mg}$ per $\mathrm{kg}$ of soil) generated in plants, where a percent reduction of $12.6,17.5$ and $16.1,18.9$ was recorded in fresh and dry mass per plant at 60 and 90 DAS, respectively, compared to the control.

Tab. 2. Effect of $10^{-5} \mathrm{M}$ salicylic acid (SA) on the Cd (0, 25, 50 or 100 $\mathrm{mg} \mathrm{kg}^{-1}$ of soil) induced changes in fresh mass and dry mass plant ${ }^{-1}(\mathrm{~g})$ in Cicer arietinum at 60 and 90 DAS. Data are the mean of three independent replicates $( \pm$ SE)

\begin{tabular}{lcccc}
\hline \multirow{2}{*}{ Treatments } & \multicolumn{2}{c}{ Fresh mass per plant $(\mathrm{g})$} & \multicolumn{2}{c}{ Dry mass per plant $(\mathrm{g})$} \\
\cline { 2 - 5 } & 60 DAS & 90 DAS & 60 DAS & 90 DAS \\
\hline Control (DDW) & $14.25^{\mathrm{c}} \pm 3.5$ & $15.82^{\mathrm{c}} \pm 4.6$ & $3.54^{\mathrm{b}} \pm 1.15$ & $3.88^{\mathrm{b}} \pm 0.80$ \\
Cd $(0 \mathrm{mg})+$ SA & $19.35^{\mathrm{a}} \pm 3.8$ & $23.21^{\mathrm{a}} \pm 4.0$ & $5.25^{\mathrm{a}} \pm 0.72$ & $6.11^{\mathrm{a}} \pm 0.75$ \\
Cd $(25 \mathrm{mg})+$ SA & $15.87^{\mathrm{b}} \pm 2.3$ & $18.75^{\mathrm{b}} \pm 4.3$ & $3.76^{\mathrm{b}} \pm 0.61$ & $4.11^{\mathrm{b}} \pm 1.15$ \\
Cd $(50 \mathrm{mg})+$ SA & $14.92^{\mathrm{bc}} \pm 4.6$ & $16.95^{\mathrm{bc}} \pm 5.2$ & $3.55^{\mathrm{b}} \pm 0.78$ & $3.89^{\mathrm{b}} \pm 0.75$ \\
Cd $(100 \mathrm{mg})+$ SA & $12.65^{\mathrm{d}} \pm 5.5$ & $14.25^{\mathrm{c}} \pm 4.0$ & $2.65^{\mathrm{c}} \pm 0.58$ & $2.88^{\mathrm{c}} \pm 0.60$ \\
\multicolumn{1}{c}{ LSD 5\% } & 1.6 & 1.8 & 0.35 & 0.45 \\
\hline
\end{tabular}

\section{Carbonic anhydrase (CA) activity in leaves}

The plants received $100 \mathrm{mg} \mathrm{Cd}$ and also sprayed with SA exhibited a lower activity of CA compared to the control, at both the sampling stages (Tab. 3). The application of SA to the foliage, however, resulted in a significant increase of $47.3 \%, 58.0 \%$ (unstressed); $28.1 \%$, $33.9 \%(25 \mathrm{mg} \mathrm{Cd})$ and $12.9 \%, 13.9 \%$ (50 mg Cd) at the two sampling stages, respectively, in the activity of CA compared to the control (Tab. 3).

Tab. 3. Effect of 10-5 M salicylic acid (SA) on the Cd (0, 25, 50 or 100 $\mathrm{mg} \mathrm{kg}{ }^{-1}$ of soil) induced changes in CA activity $\left[\mathrm{mol}\left(\mathrm{CO}_{2}\right) \mathrm{Kg}^{-1}\right.$ leaf (F.M)] and $\mathrm{gs}\left(\mathrm{mol} \mathrm{m}^{-2} \mathrm{sec}^{-1}\right)$ in Cicer arietinum at 60 and 90 DAS. Data are the mean of three independent replicates $( \pm$ SE)

\begin{tabular}{|c|c|c|c|c|}
\hline \multirow{2}{*}{ Treatments } & \multicolumn{2}{|c|}{ CA activity } & \multicolumn{2}{|c|}{$\mathrm{gs}_{\mathrm{s}}$} \\
\hline & $60 \mathrm{DAS}$ & 90 DAS & 60 DAS & $90 \mathrm{DAS}$ \\
\hline Control (DDW) & $2.56^{\mathrm{d}} \pm 0.02$ & $2.74^{\mathrm{d}} \pm 0.06$ & $0.307^{\mathrm{d}} \pm 0.003$ & $0.328^{\mathrm{d}} \pm 0.004$ \\
\hline $\mathrm{Cd}(0 \mathrm{mg})+\mathrm{SA}$ & $3.77^{a} \pm 0.02$ & $4.33^{\mathrm{a}} \pm 0.06$ & $0.400^{a} \pm 0.002$ & $0.432^{2} \pm 0.005$ \\
\hline $\mathrm{Cd}(25 \mathrm{mg})+\mathrm{SA}$ & $3.28^{\mathrm{b}} \pm 0.05$ & $3.67^{b} \pm 0.07$ & $0.359^{b} \pm 0.002$ & $0.388^{b} \pm 0.006$ \\
\hline $\mathrm{Cd}(50 \mathrm{mg})+\mathrm{SA}$ & $2.89^{c} \pm 0.03$ & $3.12^{c} \pm 0.06$ & $0.330^{c} \pm 0.004$ & $0.346^{c} \pm 0.006$ \\
\hline $\mathrm{Cd}(100 \mathrm{mg})+\mathrm{SA}$ & $2.30^{e} \pm 0.02$ & $2.46^{\mathrm{e}} \pm 0.07$ & $0.288^{e} \pm 0.001$ & $0.305^{\mathrm{e}} \pm 0.004$ \\
\hline LSD 5\% & 0.15 & 0.22 & 0.01 & 0.01 \\
\hline
\end{tabular}

\section{Photosynthetic parameters}

The foliar application of $10^{-5} \mathrm{M}$ of SA resulte Fig. $\mathrm{d}$ in a significant increase of $30.3 \%, 31.7 \%\left(\mathrm{~g}_{\mathrm{s}}\right) ; 33.1 \%, 35.6 \%(\mathrm{Ci})$; 86.8\%, $92.7 \%$ (WUE); 37.7\%, 40.1\% (E) and 59.5\%, $55.7 \%$ $\left(\mathrm{P}_{\mathrm{N}}\right)$ at 60 and 90 DAS, respectively in unstressed plants, over their controls (Tabs. 3-5). The SA treatment alleviated the stress generated by $\mathrm{Cd}$ supplemented at the rate of 25 or 50 $\mathrm{mg}$ per $\mathrm{kg}$ of soil. An increase of $16.9 \%, 18.3 \%\left(\mathrm{~g}_{\mathrm{s}}\right) ; 17.1 \%$,
15.9\% (Ci); 36.8\%, 41.5\% (WUE); 11.3\%, 10.2\% (E) and $35.0 \%, 28.9 \%\left(\mathrm{P}_{\mathrm{N}}\right)$ at 60 and $90 \mathrm{DAS}$, respectively, over the control was observed in the plants fed with $\mathrm{Cd}$ at the rate of $25 \mathrm{mg}$ per $\mathrm{kg}$ of soil and also sprayed with SA. Further the increase in $g_{s}, \mathrm{Ci}, \mathrm{WUE}, \mathrm{E}$ and $\mathrm{P}_{\mathrm{N}}$ in the plants supplemented with $\mathrm{Cd}$ at the rate of $50 \mathrm{mg}$ per $\mathrm{kg}$ of soil followed by foliar spray of SA at day 30, after sowing, was found to be $7.5 \%, 5.5 \% ; 7.3 \%, 6.2 \% ; 18.4 \%, 14.6 \% ; 5.03 \%$, $2.4 \%$ and $19.0 \%, 20.0 \%$ at 60 and 90 DAS, respectively, over control. However, the spray did not prove to be fruitful in alleviating the stress generated by Cd supplemented at the rate of $100 \mathrm{mg}$ per kg of soil (Tabs. 3-5).

Tab. 4. Effect of $10^{-5} \mathrm{M}$ salicylic acid (SA) on the Cd (0, 25, 50 or 100 $\mathrm{mg} \mathrm{kg}{ }^{-1}$ of soil) induced changes in $\mathrm{C}_{\mathrm{i}}(\mathrm{ppm})$ and WUE $\left(\mathrm{mM} \mathrm{M}^{-1}\right)$ in Cicer arietinum at 60 and 90 DAS. Data are the mean of three independent replicates $( \pm$ SE)

\begin{tabular}{|c|c|c|c|c|}
\hline \multirow{2}{*}{ Treatments } & \multicolumn{2}{|c|}{$\mathrm{C}_{\mathrm{i}}$} & \multicolumn{2}{|c|}{ WUE } \\
\hline & 60 DAS & 90 DAS & 60 DAS & $90 \mathrm{DAS}$ \\
\hline Control (DDW) & $275^{\mathrm{d}} \pm 4.1$ & $289^{\mathrm{d}} \pm 3.2$ & $0.38^{\mathrm{d}} \pm 0.02$ & $0.41^{\mathrm{d}} \pm 0.02$ \\
\hline $\mathrm{Cd}(0 \mathrm{mg})+\mathrm{SA}$ & $366^{\mathrm{a}} \pm 3.2$ & $392^{\mathrm{a}} \pm 2.3$ & $0.71^{2} \pm 0.01$ & $0.79^{\mathrm{a}} \pm 0.02$ \\
\hline $\mathrm{Cd}(25 \mathrm{mg})+\mathrm{SA}$ & $322^{\mathrm{b}} \pm 3.8$ & $335^{\mathrm{b}} \pm 2.9$ & $0.52^{b} \pm 0.06$ & $0.58^{b} \pm 0.006$ \\
\hline $\mathrm{Cd}(50 \mathrm{mg})+\mathrm{SA}$ & $295^{c} \pm 2.9$ & $307^{c} \pm 3.2$ & $0.45^{c} \pm 0.02$ & $0.47^{c} \pm 0.03$ \\
\hline $\mathrm{Cd}(100 \mathrm{mg})+\mathrm{SA}$ & $260^{\mathrm{d}} \pm 3.5$ & $271^{\mathrm{e}} \pm 3.5$ & $0.26^{\mathrm{e}} \pm 0.01$ & $0.27^{\mathrm{e}} \pm 0.006$ \\
\hline LSD 5\% & 17 & 16 & 0.05 & 0.04 \\
\hline
\end{tabular}

Tab. 5. Effect of $10^{-5} \mathrm{M}$ salicylic acid (SA) on the Cd (0, 25, 50 or 100 $\mathrm{mg} \mathrm{kg}{ }^{-1}$ of soil) induced changes in $\mathrm{E}\left(\mathrm{m} \mathrm{mol} \mathrm{m} \mathrm{mec}^{-1}\right)$ and $\mathrm{P}_{\mathrm{N}}(\mathrm{m} \mathrm{mol}$ $\left.\mathrm{CO}_{2} \mathrm{~m}^{-2} \mathrm{sec}^{-1}\right)$ in Cicer arietinum at 60 and 90 DAS. Data are the mean of three independent replicates $( \pm$ SE)

\begin{tabular}{ccccc}
\hline \multirow{2}{*}{ Treatments } & \multicolumn{2}{c}{$\mathrm{c}$} & \multicolumn{2}{c}{$\mathrm{P}_{\mathrm{N}}$} \\
\cline { 2 - 5 } & $60 \mathrm{DAS}$ & $90 \mathrm{DAS}$ & $60 \mathrm{DAS}$ & $90 \mathrm{DAS}$ \\
\hline Control (DDW) & $1.59^{\mathrm{d}} \pm 0.01$ & $1.67^{\mathrm{d}} \pm 0.01$ & $5.83^{\mathrm{d}} \pm 0.03$ & $6.36^{\mathrm{d}} \pm 0.02$ \\
Cd $(0 \mathrm{mg})+$ SA & $2.19^{\mathrm{a}} \pm 0.01$ & $2.34^{\mathrm{a}} \pm 0.006$ & $9.30^{\mathrm{a}} \pm 0.06$ & $9.90^{\mathrm{a}} \pm 0.02$ \\
$\mathrm{Cd}(25 \mathrm{mg})+$ SA & $1.77^{\mathrm{b}} \pm 0.006$ & $1.84^{\mathrm{b}} \pm 0.02$ & $7.87^{\mathrm{b}} \pm 0.06$ & $8.20^{\mathrm{b}} \pm 0.01$ \\
Cd $(50 \mathrm{mg})+$ SA & $1.67^{\mathrm{c}} \pm 0.02$ & $1.71^{\mathrm{c}} \pm 0.03$ & $6.94^{\mathrm{c}} \pm 0.02$ & $7.63^{\mathrm{c}} \pm 0.01$ \\
Cd $(100 \mathrm{mg})+$ SA & $1.35^{\mathrm{c}} \pm 0.02$ & $1.40^{\mathrm{e}} \pm 0.01$ & $5.26^{\mathrm{e}} \pm 0.6$ & $5.92^{\mathrm{d}} \pm 0.02$ \\
LSD 5 \% & 0.07 & 0.08 & 0.50 & 0.49 \\
\hline
\end{tabular}

\section{Antioxidative enzyme activities}

Application of $10^{-5} \mathrm{M}$ of SA to the foliage of unstressed plants resulted in a significant increase of $14.9 \%, 17.1 \%$ (CAT); 30.3\%, 34.9\% (POX) and 27.7\%, 30.0\% (SOD) at 60 and 90 DAS, respectively, compared to the control (Tabs. 6-7). Further, when SA was applied exogenously to the $\mathrm{Cd}$ stressed plants, a sharp increase in the activity of these antioxidant enzymes was observed that was proportionate with the concentration of the metal. The activity of CAT, POX and SOD was found to be highest under the influence of exogenous SA in the plants fed with $\mathrm{Cd}$ at the rate of $100 \mathrm{mg}$ per $\mathrm{kg}$ of soil, showing a significant increase of $33.4 \%, 38.1 \% ; 85.6 \%, 95.2 \%$ and $61.3 \%, 70.0 \%$ at 60 and 90 DAS, respectively, compared to the control. The values revealed for these parameters, in the plants fed with $\mathrm{Cd}$ at the rate of $25 \mathrm{mg}$ per $\mathrm{kg}$ of soil followed by a foliar spray of SA was found to be significantly higher by $20.5 \%, 23.8 \%$; $40.9 \%, 43.8 \%$ and $36.5 \%, 40.0 \%$ at 60 and 90 DAS, respectively, over control (Tabs. 6-7).

\section{Proline content in leaves}

The exogenous application of SA significantly increased 
443

the endogenous level of proline over control, irrespective of the $\mathrm{Cd}$ concentration used (Tab. 7). The endogenous proline level in unstressed plants was found to be $50.0 \%$ and $48.2 \%$ higher at 60 and $90 \mathrm{DAS}$, respectively, compared to the control, in response to exogenous SA. Further, the proline level in response to the foliar applied SA, increased linearly with increasing concentration of $\mathrm{Cd}$ and was found to be $57.0 \%, 56.8 \%$ ( $25 \mathrm{mg} \mathrm{Cd}$ ); $68.1 \%, 62.0 \%$ (50 $\mathrm{mg} \mathrm{Cd}$ ) and $92.4 \%, 90.6 \%$ (100 $\mathrm{mg} \mathrm{Cd}$ ) higher, compared to the control at 60 and 90 DAS, respectively (Tab. 7).

Tab. 6. Effect of $10^{-5} \mathrm{M}$ salicylic acid (SA) on the Cd (0, 25, 50 or 100 $\mathrm{mg} \mathrm{kg}{ }^{-1}$ of soil) induced changes in CAT $\left[\mu\right.$ mol $\mathrm{H}_{2} \mathrm{O}_{2}$ decomposed $\mathrm{g}^{-1}$ (FM)] and POX [units g ${ }^{-1}$ (FM)] activities in Cicer arietinum at 60 and 90 DAS. Data are the mean of three independent replicates $( \pm$ SE)

\begin{tabular}{lcccc}
\hline \multirow{2}{*}{ Treatments } & \multicolumn{2}{c}{ CAT } & \multicolumn{2}{c}{ POX } \\
\cline { 2 - 5 } & 60 DAS & 90 DAS & 60 DAS & 90 DAS \\
\hline Control (DDW) & $395^{\mathrm{e}} \pm 3.5$ & $415^{\mathrm{e}} \pm 4.6$ & $13.2^{\mathrm{d}} \pm 1.15$ & $14.6^{\mathrm{d}} \pm 0.80$ \\
Cd $(0 \mathrm{mg})+$ SA & $454^{\mathrm{d}} \pm 3.8$ & $486^{\mathrm{d}} \pm 4.0$ & $17.2^{\mathrm{c}} \pm 0.72$ & $19.7^{\mathrm{c}} \pm 0.75$ \\
Cd $(25 \mathrm{mg})+$ SA & $476^{\mathrm{c}} \pm 2.3$ & $514^{\mathrm{c}} \pm 4.3$ & $18.6^{\mathrm{c}} \pm 0.61$ & $21.0^{\mathrm{c}} \pm 1.15$ \\
Cd $(50 \mathrm{mg})+$ SA & $497^{\mathrm{b}} \pm 4.6$ & $545^{\mathrm{b}} \pm 5.2$ & $21.8^{\mathrm{b}} \pm 0.78$ & $25.3^{\mathrm{b}} \pm 0.75$ \\
Cd $(100 \mathrm{mg})+$ SA & $527^{\mathrm{a}} \pm 5.5$ & $573^{\mathrm{a}} \pm 4.0$ & $24.5^{\mathrm{a}} \pm 0.58$ & $28.5^{\mathrm{a}} \pm 0.60$ \\
\hline LSD 5\% & 16 & 18 & 2.0 & 2.8 \\
\hline
\end{tabular}

Tab. 7. Effect of $10^{-5} \mathrm{M}$ salicylic acid (SA) on the Cd (0, 25, 50 or 100 $\mathrm{mg} \mathrm{kg}^{-1}$ of soil) induced changes in SOD [units $\mathrm{g}^{-1}$ (FM)] activity and proline content $\left[\mathrm{mg} \mathrm{g}^{-1}(\mathrm{FM})\right]$ in Cicer arietinum at 60 and 90 DAS. Data are the mean of three independent replicates $( \pm$ SE)

\begin{tabular}{lcccc}
\hline \multirow{2}{*}{ Treatments } & \multicolumn{2}{c}{ SOD } & \multicolumn{2}{c}{ Proline content } \\
\cline { 2 - 5 } & 60 DAS & 90 DAS & 60 DAS & 90 DAS \\
\hline Control (DDW) & $137^{\mathrm{d}} \pm 3.2$ & $150^{\mathrm{d}} \pm 3.8$ & $10.00^{\mathrm{c}} \pm 0.11$ & $11.81^{\mathrm{c}} \pm 0.15$ \\
Cd $(0 \mathrm{mg})+$ SA & $175^{\mathrm{c}} \pm 2.6$ & $195^{\mathrm{c}} \pm 3.5$ & $15.00^{\mathrm{d}} \pm 0.15$ & $17.50^{\mathrm{d}} \pm 0.17$ \\
\hline $\mathrm{Cd}(25 \mathrm{mg})+$ SA & $187^{\mathrm{bc}} \pm 3.5$ & $210^{\mathrm{bc}} \pm 3.2$ & $15.7^{\mathrm{c}} \pm 0.18$ & $18.52^{\mathrm{c}} \pm 0.20$ \\
Cd $(50 \mathrm{mg})+$ SA & $200^{\mathrm{b}} \pm 4.0$ & $225^{\mathrm{b}} \pm 2.9$ & $16.81^{\mathrm{b}} \pm 0.1$ & $19.13^{\mathrm{b}} \pm 0.12$ \\
\hline Cd $(100 \mathrm{mg})+$ SA & $221^{\mathrm{a}} \pm 2.9$ & $255^{\mathrm{a}} \pm 4.0$ & $19.24^{\mathrm{a}} \pm 0.2$ & $22.51^{\mathrm{a}} \pm 0.11$ \\
\multicolumn{1}{c}{ LSD 5\% } & 18 & 23 & 0.5 & 0.6 \\
\hline
\end{tabular}

\section{Number of podsperplant}

Application of SA to the foliage of unstressed plants resulted in a significant increase of $57.8 \%$ (number of pods) over control. Further the treatment also proved to be fruitful in increasing the number of pods in the plants fed with $\mathrm{Cd}(25$ or $50 \mathrm{mg})$ and also received SA where a significant increase of $32.4 \%$ and $13.0 \%$ in the number of pods per plant was observed respectively over control. Further, like other parameters the foliar application of SA proved to be inefficient in alleviating the stress generated by $\mathrm{Cd}(100 \mathrm{mg})$, where $11.7 \%$ reduction in this parameter was observed compared to the control (Tab. 8).

Tab. 8. Effect of $10^{-5} \mathrm{M}$ of salicylic acid on the Cd (0, 25, 50 or $100 \mathrm{mg}$ per of soil) induced changes in yield characteristics in chickpea. Data are the mean of three independent replicates. LSD is the least significant difference

\begin{tabular}{lcccc}
\hline Treatments & $\begin{array}{c}\text { Number of } \\
\text { pods per } \\
\text { plant }\end{array}$ & $\begin{array}{c}\text { Seed yield }(\mathrm{g} \\
\text { plant }\end{array}$ & $\begin{array}{c}100 \text { seeds } \\
\text { mass }(\mathrm{g})\end{array}$ & $\begin{array}{c}\text { Seed protein } \\
\text { content }(\%)\end{array}$ \\
\hline Control $(\mathrm{DDW})$ & $18.50^{\mathrm{d}} \pm 1.7$ & $6.18^{\mathrm{d}} \pm 0.7$ & $14.55^{\mathrm{d}} \pm 1.3$ & $19.20^{\mathrm{d}} \pm 2.1$ \\
$\mathrm{Cd}(0 \mathrm{mg})+$ SA & $29.20^{\mathrm{a}} \pm 3.2$ & $12.85^{\mathrm{a}} \pm 1.3$ & $22.81^{\mathrm{a}} \pm 1.9$ & $21.89^{\mathrm{a}} \pm 2.4$ \\
$\mathrm{Cd}(25 \mathrm{mg})+$ SA & $24.50^{\mathrm{b}} \pm 2.6$ & $9.51^{\mathrm{b}} \pm 1.0$ & $20.50^{\mathrm{b}} \pm 1.8$ & $20.74^{\mathrm{b}} \pm 2.1$ \\
$\mathrm{Cd}(50 \mathrm{mg})+$ SA & $20.91^{\mathrm{c}} \pm 2.1$ & $7.11^{\mathrm{c}} \pm 0.8$ & $17.50^{\mathrm{c}} \pm 1.4$ & $20.10^{\mathrm{c}} \pm 1.9$ \\
\hline $\mathrm{Cd}(100 \mathrm{mg})+$ SA & $16.33^{\mathrm{e}} \pm 1.7$ & $4.90^{\mathrm{e}} \pm 0.6$ & $13.80^{\mathrm{d}} \pm 1.1$ & $17.50^{\mathrm{e}} \pm 1.6$ \\
\hline LSD $5 \%$ & 1.2 & 0.5 & 0.9 & 0.5 \\
\hline
\end{tabular}

\section{Seed yield, 100 seed mass and seed protein content}

The exogenous foliar application of $10^{-5} \mathrm{M}$ of SA significantly increased the seed yield, 100 seed mass and seed protein content in unstressed plants by $108 \% ; 56.8 \%$ and $14.0 \%$ respectively, over control (Tab. 8). Further, the SA treatment to the plants already fed with $\mathrm{Cd}(25$ or $50 \mathrm{mg}$ per $\mathrm{kg}$ soil) significantly increased the values of seed yield, 100 seeds mass and seed protein content over that of control. The percent increase recorded in these parameters was found to be $53.9 \%, 40.9 \%$ and $8.0 \%(\mathrm{Cd} 25 \mathrm{mg})$ and $15.0 \%, 20.3 \%$ and $5.0 \%(\mathrm{Cd} 50 \mathrm{mg})$, respectively, over that of the control. However, the foliar spray of SA to the plants already supplemented with $100 \mathrm{mg}$ Cd exhibited $20.0 \%$, $5.0 \%$ and $8.8 \%$ reduction in seed yield, 100 seeds mass and seed protein content, respectively, compared to the control (Tab. 8).

Beside this promising response of SA on photosynthesis, SA has ability to conferred tolerance to barley seedlings and maize plants against oxidative stress induced by $\mathrm{Pq}$ (Paraquat) and Cd respectively (Krantev et al., 2008). Accumulation of reactive oxygen species i.e. oxidative stress that cause extensive damage including lipid peroxidation, chlorophyll breakdown, loss of photosynthetic activity and membrane integrity, as well as electrolyte leakage. However, Krantev et al. (2008) observed in maize plants that pretreated with $0.5 \mathrm{mM}$ SA before exposure to $10-25 \mathrm{mM}$ cadmium, protection of photosynthesis conferred by SA could be the result of a very rapid detoxification of ROS. It has been demonstrated in different plants species that pretreatment with low concentrations of SA enhances tolerance toward most kinds of abiotic stresses due to an enhanced antioxidant capacity (Horváth et al., 2007). Similar response was observed in the present study where SA $\left(10^{-5} \mathrm{M}\right)$ significantly increased the antioxidant enzymes (CAT, POX, and SOD) compared to control (Tabs. 6-7) in the presence and absence of $\mathrm{Cd}$ along with increased accumulation of proline in SA treated plants (Tab. 7). Moreover, proline plays vital role in wide range of protective responses including osmotic adjustment, stabilizer for cellular structure and reducing damage to photosynthetic apparatus (Nounjan et al., 2012). Hossain et al. (2011) demonstrated that exogenous proline provided a protective action against abiotic stress-induced oxidative damage by reducing $\mathrm{H}_{2} \mathrm{O}_{2}$ and lipid peroxidation level and by enhancing antioxidant defense and methylglyoxal detoxification systems. In addition to this, exogenous proline also prevents protein aggregation and stabilization of M4 lactate dehydrogenase during extreme temperatures, protection of nitrate reductase during heavy metal and osmotic stress (Szabados and Savouré, 2010).

The accelerated photosynthesis and its related attributes, enhanced proline accumulation coupled with the increased activity of antioxidative enzymes in Cd stressed plants in the presence of exogenously applied $10^{-5} \mathrm{M}$ of SA is naturally expected to increase the growth of plants which was reflected in the form of increased length, fresh and dry mass of root and shoot per plant (Tabs. 1-2). Further, the enhanced growth characteristics of $\mathrm{Cd}$ fed plants sprayed with $10^{-5} \mathrm{M}$ of SA might also be due to the fact that SA acts at the level of transcription and/or translation thereby increasing the activity of various other enzymes necessary for growth of plants (Hayat et al., 2010). Moreover, SA also 
promotes cell division and cell enlargement (Hayat et al., 2013). This increased growth under the influence of exogenous SA is likely to increase the yield characteristics (Tab. 8). The plausible reason for increasing the crop yield might be due to delayed senescence of plant organs (particularly leaves and flowers) in response to exogenous SA (Imran et al., 2007) that will automatically help the plant in extending the duration of photosynthetically active sites and also prevent the premature loss of flowers and fruits. This consequently resulted in the observed increase in the number of pods per plant (Tab. 8). It gets additional support from the observations of Marschner (2012) that phytohormones increase the degree of sink at the level of seeds, directing the flow of metabolites to the developing seeds increasing the seed protein content (Tab. 8) consequent to an improvement in the seed mass (Tab. 8) and seed yield per plant at harvest (Tab. 8).

\section{Conclusions}

The present investigation revealed that exogenously applied $10^{-5} \mathrm{SA}$ plays significant role to protect the photosynthetic machinery under $\mathrm{Cd}$-stressed plants. In addition to this, SA also enhanced the activities of antioxidant enzymes and proline accumulation that confer tolerance to Cd-stressed plants and enhanced the yield characteristics.

\section{Acknowledgements}

The authors extend their appreciation to the Deanship of Scientific Research at King Saud University for funding the work through the research group project No. RGPVPP-199.

\section{References}

Arfan M, Athar HR, Ashraf M (2007). Does exogenous application of salicylic acid through the rooting medium modulate growth and photosynthetic capacity in two differently adapted spring wheat cultivars under salt stress? J Plant Physiol 164(6):685-694.

Bal W, Liang R, Lukszo J, Lee S-H, Dizdaroglu M, Kasprzak KS (2000). Ni (II) specifically cleaves the C-terminal tail of the major variant of histone $\mathrm{H} 2 \mathrm{~A}$ and forms an oxidative damagemediating complex with the cleaved-off octapeptide. Chem Res Toxicol 13(7):616-624.

Barcelo J, Poschenrieder C (1990). Plant water relations as affected by heavy metal stress: a review. Journal of Plant Nutrition 13(1):1-37.

Bates LS, Walden RT, Tearse ID (1973). Rapid determination of free proline for water stress studies. Plant Soil 39:205-207.

Bazzas FA, Carlson RW, Rolfe GL (1974). The effect of heavy metals on plants. Environ Poll 7:241-246.

Beauchamp C, Fridovich I (1971). Superoxide dismutase: improved assays and an assay applicable to acrylamide gels. Analytical biochemistry 44(1):276-287.

Chance B, Maehly AC (1956). Assay of catalase and peroxidase.
Method Enzymol 2:764-775.

Dwivedi RS, Randhawa NS (1974). Evolution of a rapid test of the hidden hunger of zinc in plants. Plant Soil 40:445-451.

Foy C, Chaney Rt, White M (1978). The physiology of metal toxicity in plants. Ann Rev Plant Physio 29(1):511-566.

Foyer CH, Noctor G (2003). Redox sensing and signalling associated with reactive oxygen in chloroplasts, peroxisomes and mitochondria. Physiol Plantarum 119(3):355-364.

Gémes K, Poór P, Sulyok Z, Szepesi Á, Szabó M, Tari I (2008). Role of salicylic acid pre-treatment on the photosynthetic performance of tomato plants (Lycopersicon esculentum Mill. L. cv. Rio Fuego) under salt stress. Acta Biol Szeg 52(1):161162.

Gratão PL, Polle A, Lea PJ, Azevedo RA (2005). Making the life of heavy metal-stressed plants a little easier. Funct Plant Biol 32(6):481-494.

Hasan SA, Fariduddin Q, Ali B, Hayat S, Ahmad A (2009). Cadmium: Toxicity and tolerance in plants. J Environ Biol 30(2):165-174.

Hasan SA, Hayat S, Ali B, Ahmad A (2008). 28-homobrassinolide protects chickpea (Cicer arietinum) from cadmium toxicity by stimulating antioxidants. Environmental pollution 151(1):60-66.

Hayat Q, Hayat S, Irfan M, Ahmad A (2010). Effect of exogenous salicylic acid under changing environment: A review. Env Exp Bot 68(1):14-25.

Hayat S, Ali B, Hasan SA, Ahmad A (2007). Brassinosteroid enhanced the level of antioxidants under cadmium stress in Brassica juncea. Env Exp Bot 60(1): 33-41.

Hayat S, Ahmad A, Alyemeni MN (2013). Salicylic Acid: Plant Growth and Development. Springer, Dordrecht, The Netherlands.

Hermans C, Johnson GN, Strasser RJ, Verbruggen N (2004). Physiological characterisation of magnesium deficiency in sugar beet: acclimation to low magnesium differentially affects photosystems I and II. Planta 220(2):344-355.

Horváth E, Szalai G, Janda T (2007). Induction of abiotic stress tolerance by salicylic acid signaling. J Plant Growth Regul 26(3):290-300.

Hossain MA, Hasanuzzaman M, Fujita M (2011). Coordinate induction of antioxidant defense and glyoxalase system by exogenous proline and glycinebetaine is correlated with salt tolerance in mung bean. Front Agric China 5(1):1-14.

Irfan M, Hayat S, Ahmad A, Alyemeni MN (2013). Soil cadmium enrichment: Allocation and plant physiological manifestations. Saudi J Biol Sci 20:1-10.

Imran H, Zhang Y, Du G, Wang G, Zhang J (2007). Effect of salicylic acid (SA) on delaying fruit senescence of Huang Kum pear. Front Agric China 1(4):456-459.

Janda T, Horváth E, Szalai G, Paldi E (2007). Role of salicylic acid in the induction of abiotic stress tolerance, p. 91-150. In: Hayat S, Ahmad P (eds) Salicylic acid: a plant hormone. Springer, Dordrecht, The Netherlands. 
445

Krantev A, Yordanova R, Janda T, Szalai G, Popova L (2008). Treatment with salicylic acid decreases the effect of cadmium on photosynthesis in maize plants. J Plant Physiol 165(9):920931.

Krupa Z, Öquist G, Huner NPA (1993). The effects of cadmium on photosynthesis of Phaseolus vulgaris - a fluorescence analysis. Physiol Plant 88(4):626-630.

Landberg T, Greger M (2002). Differences in oxidative stress in heavy metal resistant and sensitive clones of Salix viminalis. J Plant Physiol 159(1):69-75.

Larsen PB, Degenhardt J, Tai CY, Stenzler LM, Howell SH, Kochian LV (1998). Aluminum-resistant Arabidopsis mutants that exhibit altered patterns of aluminum accumulation and organic acid release from roots. Plant physiology 117(1):9-18.

Lowry OH, Rosebrough NJ, Farr AL, Randall RJ (1951). Protein measurement with the Folin phenol reagent. The Journal of biological chemistry 193(1):265-275.

Marschner H (2012). Nitrogen fixation, p. 389-408. In: Marschner P (ed). Marschner's mineral nutrition of higher plants. Academic Press, United States of America.

Métraux J-P (2002). Recent breakthroughs in the study of salicylic acid biosynthesis. Trends Plant Sci 7(8):332-334.

Mishra A, Choudhuri M (1997). Ameliorating effects of salicylic acid on lead and mercury: induced inhibition of germination and early seedling growth of two rice cultivars. Seed Sci Technol 25(2):263-270.

Nounjan N, Nghia PT, Theerakulpisut P (2012). Exogenous proline and trehalose promote recovery of rice seedlings from salt-stress and differentially modulate antioxidant enzymes and expression of related genes. J Plant Physiol 169(6):596604.

Poór P, Gémes K, Horváth F, Szepesi A, Simon M, Tari I (2011). Salicylic acid treatment via the rooting medium interferes with stomatal response, $\mathrm{CO}_{2}$ fixation rate and carbohydrate metabolism in tomato, and decreases harmful effects of subsequent salt stress. Plant Biol 13(1):105-114.

Reddy MP, Vora AB (1986). Changes in pigment composition, hill reaction activity and saccharide metabolism in bajra (Pennisetum typhoides S\&H) leaves under $\mathrm{NaCl}$ salinity. Photosynthetica 20:50-55.

Sahu G, Kar M, Sabat S (2002). Electron transport activities of isolated thylakoids from wheat plants grown in salicylic acid. Plant Biol 4(3):321-328.

Sanita di Toppi L, Gabbrielli R (1999). Response to cadmium in higher plants. Environ Exp Bot 41(2):105-130.

Sheoran IS, Signal HR, Singh R (1990). Effect of cadmium and nickel on photosynthesis and the enzymes of photosynthetic carbon reduction cycle in pigeon pea (Cajanus cajan L.). Photosynth Res 23(3):345-351.

Singh B, Usha K (2003). Salicylic acid induced physiological and biochemical changes in wheat seedlings under water stress. Plant Growth Regul 39(2):137-141.

Sinha S, Srivastava H, Tripathi R (1994). Influence of some growth regulators and divalent cations on the inhibition of nitrate reductase activity by lead in maize leaves. Chemosphere 29(8):1775-1782.

Skórzyńska-Polit E, Krupa Z (2006). Lipid peroxidation in cadmium-treated Phaseolus coccineus plants. Arch Environ Con Tox 50(4):482-487.

Szabados L, Savouré A (2010). Proline: a multifunctional amino acid. Trends Plant Sci 15(2):89-97.

Tran TA, Popova LP (2013). Functions and toxicity of cadmium in plants: recent advances and future prospects. Turk J Bot 37(1):1-13.

Van Assche F, Clijsters H (1990). Effects of metals on enzyme activity in plants. Plant Cell Environ 13(3):195-206. 